\title{
A transdisciplinary educational experience at the Botanical Garden around scientific travelers
}

\section{Yolanda Echegoyen Sanz ${ }^{1}$, Antonio Martín Ezpeleta ${ }^{2}$}

${ }^{1}$ Department of Experimental and Social Sciences Didactics, University of Valencia, Spain, ${ }^{2}$ Department of Languaje and Literature Didactics, University of Valencia, Spain.

\begin{abstract}
In the framework of the transdisciplinary educational innovative project "Sciences and Arts" at the University of Valencia, we present here the design and outcome of an activity around the phenomenon of scientific travelers. It consisted in a scientific-literary tour through the Botanical Garden of the University of Valencia, which 100 students from the subjects "Natural Sciences for teachers" and "Literary training for teachers" attended together. The activity was designed as a collaborative work in which scientific travelers served as a pretext to address six educational aspects that the students from each subject tackled in two different ways: from a more scientific than literary approach and viceversa. The students valued very much the possibility of interaction with the other group, the fact that the expositions took place at a natural environment, the integrating of Sciences and Arts and the didactic transposition carried out.
\end{abstract}

Keywords: Scientific travelers; transdisciplinarity; preservice teachers. 


\section{A commitment to transdisciplinarity on teacher education. The innovative project "Sciences and Arts"}

Since the early 1970's when the term was created and considered "still a dream" (Apostel, 1972: 138), transdisciplinarity has developed and is now related to synoptic disciplines (i.e. Geography, Philosophy, Religious Studies), comprehensive paradigms (i.e. Feminism, Marxism) or broad interdisciplinary fields (i.e. Cultural Studies) (Thompson Klein, 2004). It tries to create bridges between different areas of knowledge, as Nicolescu explains in his Manifesto of Transdisciplinarity (2002).

In Spain, there are a number of studies that reveal the need for curricular changes with the aim of integrating Experimental Sciences and Arts. The epistemological development of an environmental competence, and even the impulse of environmental classrooms and the design of didactic materials destined to the different educational levels are needed (Ull et al., 2014; Vilches Peña \& Gil Pérez, 2015). These studies also highlight the lack of teachers in our country trained to face the environmental education of the 21st century.

In this context, the innovative educational project "Sciences and Arts" tries to address some of these issues. It was founded at the Faculty of Education of the University of Valencia in Spain during the academic year 2017-2018 and tries to break the departmental walls. Currently ten professors of three different disciplines (three professors of Literature, three of Social Sciences and four of Experimental Sciences) participate. Its purpose is to design didactic materials inspired in the integration of Sciences and Arts as well as explore their educational possibilities with pre-service teachers.

In short, the project "Sciences and Arts" is trying to develop a new way of teaching and assess its performance and use. Concretely we have explored different phenomena as feminism, environmental problems, knowledge transfer and scientific travelers.

The idea is that literary texts are a first-order resource for working sciences and that scientific content and reflection on environmental protection are not incompatible with Literature lessons. Renewing the processes of teaching and learning also require changing the educational system, as freirean pedagogy postulates. This point of view is aligned with an horizontal and interdisciplinary knowledge and basically incompatible with an inflexible, tight and curricular system based on monographic studies. Our ultimate goal with these activities is to promote the knowledge of students in relevant subjects as Language, Literature or Science, but always mixing together knowledge from those areas and subjecting them to a holistic, real and ethical training, including aspects related to ecology and environmental protection, but also civic responsibility or empathy.

In addition, it has been pointed out (Martín Ezpeleta and Echegoyen Sanz, 2018) that the nature of the Faculty of Education is a good environment for the students (who will be the 
teachers of the future) to internalise the benefits of a way of learning completely aligned with the reality of teachers in schools. We cannot forget that, beyond the curricula, the task of teachers in schools is to integrate very heterogeneous contents and competences in their classes, which are not as tightly compartmentalized in subjects and specialties as in Secondary or Higher Education.

\section{Didactic proposal around scientific travelers}

We addressed the phenomenon of scientific travelers from a double perspective: the knowledge of the most relevant scientific travelers and the genre of travel journals and letters. We paid particular attention to the figure of Charles Darwin and his Voyage of the Beagle around the world between 1831 and 1836, that ultimate lead the author to publish his "Theory of Evolution”, as well as to Alexander von Humboldt and the exploration of America between 1799 and 1804. In this case, in addition, we brought up his visit to the city of Valencia, of which he leaves a mark in his diaries, and his epistolary relationship with the Valencian botanist Antonio José de Cavanilles.

The key of the didactic activities prepared around scientific travelers is that they were implemented at the same time in prototypical subjects of Sciences and Arts at the Faculty of Education, such as "Natural Sciences for teachers" and "Literary training for teachers”. Both are compulsory subjects, taught in the sophomore year of the Bachelor degrees in Early Childhood Education and Primary Education (in the case of the University of Valencia).

\subsection{Objectives}

1) To use scientific travelers to work (autonomously and collaboratively) contents and competences tradicionally related to Sciences and Arts in typical subjects of both disciplines.

2) To design transdisciplinary didactic materials for children around the topic of travelling and discovery.

3) To carry our a scientific-literary itinerary through the Botanical Garden with alumni from two subjects where a selection of the main conclusions and prepared didactic materials where shown, achieving a significative and peer learning.

4) To develop transversal competences, especially the communicative competence.

\subsection{Methodology}

With the aim of integrating Experimental Sciences and Arts in teacher education we use the phenomenon-based learning methodology (Symeonidis, \& Schwarz, 2016) with the influence of Cultural Studies, which purpose is to train responsible citizens, as proposes Henri Giroux (2004). This approach advocates for integrating knowledge and skills of many diverse disciplines around a key phenomenon. In this manner, phenomena such as climate change or 
biodiversity protection are not only studied from the Physics, Biology, Economy or Ecology points of view but also from Literature, Cinema or History. Based on this, we specify a series of methodological aspects:

1) The selected phenomenon is scientific travelers, which is associated with others like climate change, biodiversity loss or science fiction.

2) All the activities/tasks integrated contents and competences traditionally assigned to Sciences or Arts.

3) Collaborative learning and creativity are promoted, integrating the use of ICTs.

4) Transversal competences like communicative competence or gender equality are also addressed.

\section{Scientific-literary tour through the Botanical Garden of the University of Valencia}

The main activity from those around scientific travelers was a Scientific-literary tour through the Botanical Garden of the University of Valencia. The site was selected because it is well established that the nexus of experience and place offers significant promise for educational endeavours (Hill, 2013). This learning experience was aimed at utilising a holistic pedagogy engaging kinaesthetic/physical, sensory, and emotional facets of learning, as well as cognitive. One hundred alumni of two subjects "Literary training for teachers" and "Natural Sciences for teachers” participated. Each stop of the tour contained a common educational synthesis, which the students of both subjects had tackled in different ways.

The work was designed as jigsaw classroom (Aronson, 2002) in which each group was an expert on one topic (two different groups per topic) and explained it to the rest in two phases: first in a short exposition in the classroom to their classmates and then on a scientific-literary tour that both groups attended together at the Botanical Garden of the University of Valencia. The first exposition served so that the whole group could take advantage of the work of the companions and served as a general rehearsal for the exposition that would take place on the aforementioned scientific-literary tour. Each class was divided into twelve groups, in such a way that each topic was studied by two groups.

\subsection{Preparing the activity. In the classroom}

We designed a collaborative work with a duration of five classroom sessions (in addition to the self learning work) in which the alumni had to train in scientific and literary aspects at the same time. It was a project of the whole group composed of tasks carried out by small random groups of up to four students, who were going to study multidisciplinary documentation and materials provided by the teachers and organized around six scientificliterary topics. 
These topics covered different educational dimensions related to the phenomenon of scientific travelers. They were materialized in two types of analysis, one from a more literary than scientific point of view, and another, from a more scientific than literary point of view. They wanted to be complementary and help reach the educational synthesis, as shown in Table 1.

Table 1. Educational synthesis and topics for both subjects.

\begin{tabular}{|c|c|c|}
\hline $\begin{array}{l}\text { Educational } \\
\text { synthesis }\end{array}$ & $\begin{array}{c}\text { "Natural Sciences for } \\
\text { teachers" }\end{array}$ & "Literary training for teachers" \\
\hline $\begin{array}{c}\text { Travelling as a } \\
\text { personal and } \\
\text { professional training }\end{array}$ & $\begin{array}{c}\text { The great scientific expeditions. } \\
\text { Humboldt's journey }\end{array}$ & $\begin{array}{l}\text { Scientific travelers in their letters. } \\
\text { Alexander von Humboldt }\end{array}$ \\
\hline The culture of flowers & Darwin's flower & $\begin{array}{c}\text { The flowers of reason. Rubén Darío’s } \\
\text { roses }\end{array}$ \\
\hline $\begin{array}{l}\text { Literature as a } \\
\text { travelling companion }\end{array}$ & $\begin{array}{l}\text { The discovery of pinnaple (and } \\
\text { other foods) in the indian } \\
\text { chronicles }\end{array}$ & $\begin{array}{l}\text { Diaries and chronicles of Christopher } \\
\text { Columbus and Washington Irving, a } \\
\text { round trip }\end{array}$ \\
\hline $\begin{array}{l}\text { The recognition of } \\
\text { professional women }\end{array}$ & The quiet voice of women & $\begin{array}{l}\text { The quiet voice of women. María } \\
\text { Cegarra Salcedo }\end{array}$ \\
\hline $\begin{array}{l}\text { Environmental } \\
\text { protection }\end{array}$ & $\begin{array}{l}\text { Environmental humanities for } \\
\text { children }\end{array}$ & $\begin{array}{l}\text { Ecocriticism for children. The stories of } \\
\text { Jen Green and Mike Gordon on } \\
\text { environmental education }\end{array}$ \\
\hline The beauty of nature & The natural beauty & $\begin{array}{l}\text { Writers who were scientists and } \\
\text { scientists who wrote. The aphoristic } \\
\text { literature of Wolfgang von Goethe and } \\
\text { Jorge Wagensberg }\end{array}$ \\
\hline
\end{tabular}

The bibliographical references and materials of each topic in the different subjects were a combination of academic texts, either from the fields of Philology, Natural Sciences, Literature Didactics and Experimental Sciences Didactics, among which were articles published in specific journals, book chapters and even doctoral theses. On the other hand, in both subjects the reading of popular science texts, published for the most part in the periodical press, was promoted.

In both subjects the six topics were studied in three phases. Firstly the topics in question had to be assimilated from the bibliographical references and texts provided by the professors (and any other that they wanted to search from themselves), who during the face-to-face sessions were in charge of making sure that were understood by the students. Then they had 
to prepare a brief presentation that would explain their topic to their classmates. And finally they had to make a didactic transposition (Chevallard, 1988) of what they had learned. To do so, they had to design some didactic activities for children.

\subsection{Carrying out the activity. At the Botanical Garden}

The tour around the Botanical Garden was designed in a way that each topic was related to a particular place inside the Garden (i.e., "Darwin's flower” was explained at the greenhouse were the actual orchid grows, the topics about Christopher Columbus and the American discovery were explained at the tropical plants greenhouse, etc.), the itinerary with the stops is shown in Figure 1.

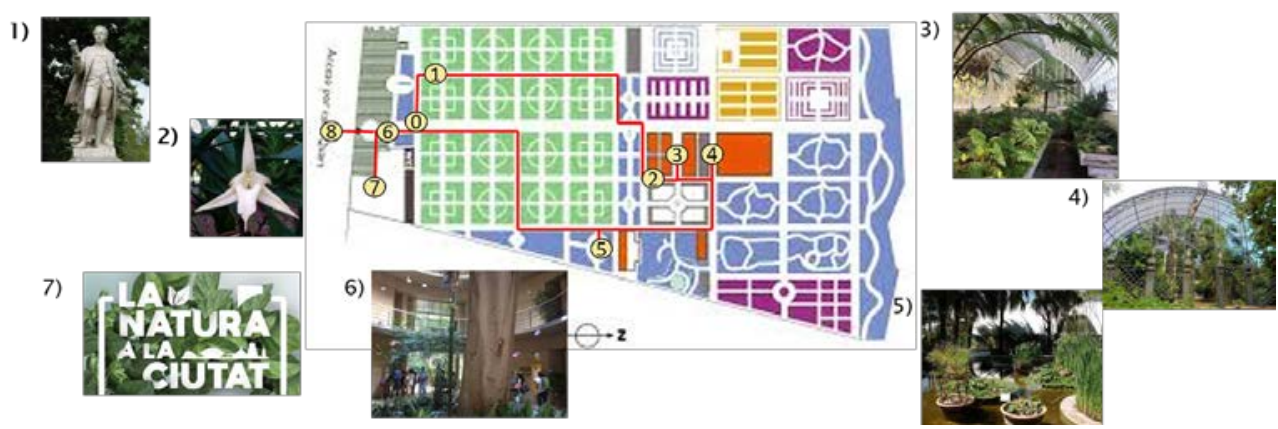

Figure 1. Itinerary and stops at the Botanical Garden .

The scientific-literary tour was carried out twice, distributing half of each group of "Literary training for teachers" and "Natural Sciences for teachers" in one day so that classes and disciplines were mixed up and the six educative synthesis with both perspectives were listened by all students. The objective was to cross the expositions that had been prepared in the context of different disciplines and with different biases, to invite students to delve into the scientific-literary issues from different and complementary perspectives, but also to experience the benefits of transdisciplinary projects.

The intervention of each group of students had three parts: reading of a text of their choosing related to their topic (some read a poem, others a letter, a fragment of a novel...); a short exposition of the topic they had worked on; and explaining in detail one of the didactic activities aimed at Primary Education children from the three or four they had prepared, showing some materials (texts, images, stories, objects, etc.).

To dinamize the activity a diary of the tour were the students could show their impressions and opinions was written voluntarily during the itinerary and a twitter contest (@ciencylet, \#cienciasyletrasnaturalmente) took place to select the best photo. 


\subsection{Evaluating the activity. Students' assessment}

The students were asked to select their favourite activity of the semester and $82.4 \%$ selected the scientific-literary tour through the Botanical Garden. When asked about which aspect of the activity they valued the most, 92.1\% selected the exposition at the Botanical Gardens and $7.9 \%$ selected the exposition in the classroom.

The students opinions, that they were asked to write in the form of a short assessment, were all very positive. Here we present some fragments: “After preparing, with great enthusiasm, the exposition, the activities and their materials the big day of the excursion to the Botanical Garden arrived. Just before entering we were informed of the hashtag that had to be used and I was excited by the idea, since two of the things that I liked doing the most were united: flowers and nature with photography (A.M.)"; "When we got there, we met with the group of students in the Literary Training class, the main idea was to show our work, since they were related to each other, but treated from the scientific and literary point of view. This is a very enriching practice, since both contents complemented each other and gave rise to a more complete sense of what was being explained (V.O.)"; "With this visit it was shown how Literature and Sciences are transversal instruments through which the learning of concepts and processes belonging to these two disciplines can be promoted and facilitated. Literature can bring science to students who are not so interested in it or the reverse process can happen, that through science a student will discover the world of literature and see how related they are to each other (I.R.)"; or "At the tour it was very enjoyable to go walking through the Botanical Garden and alternate the places of explanation, because we could travel a lot of spaces that, in one way or another, were related to the expositions, such as Darwin's flower (I.F.)”.

\section{Conclusions}

We have been able to integrate contents and competences of different disciplines around activities like the one here detailed about scientific travelers with this educational innovation project revolving around phenomenon-based learning. In addition we highlighted two key figures in the History of Science as Charles Darwin and Alexander von Humboldt (this last unknown by most of the students).

The opinion of the students about the different activities were very positive. They especially valued the possibility to be in contact with students from other groups and the fact of learning in a natural environment. They also highlighted the integration of Sciences and Arts and the reflection that entailed, as well as the opportunity to prepare some materials for children during the didactic transposition.

We propose that these phenomena and didactic activities can structure the official educational curricula in the future, in contrast to the general rule of organization in separate scientific 
disciplines. The pretension to integrate contents and competences in a learning that turns around the resolution of problems, which stimulates the empathy, curiosity and motivation of the students is old, but until now it has not permeated the dominant educational system. The combination of all these ingredients can only offer a positive result, which is precisely a holistic, real and ethical education.

\section{References}

Apostel, L. (1972). Interdisciplinarity Problems of Teaching and Research in Universities. Paris: OECD.

Aronson, E. (2002). Building empathy, compassion, and achievement in the jigsaw classroom. Improving academic achievement: Impact of psychological factors on education, 209-225.

Chevallard, Y. (1988). On didactic transposition theory: some introductory notes. Communication, international symposium on research and development in mathematics education. Bratislava, August 3-7, 1988. Retrieved from http://yves.chevallard.free.fr/spip/spip/IMG/pdf/On_Didactic_Transposition_Theory.pd f.

Giroux, H. (2004). Cultural studies, public pedagogy, and the responsibility of intellectuals. Communication and critical/cultural studies, 1(1), 59-79.

Hill, A. (2013). The Place of Experience and the Experience of Place: Intersections Between Sustainability Education and Outdoor Learning. Australian Journal of Environmental Education, 29(1), 18-32.

Martín-Ezpeleta, A., \& Echegoyen-Sanz, Y. (2018). Environmental Humanities in preservice teachers' Education. Journal of Education Culture and Society, 9(2), 52-64.

Nicolescu, B. (2002). Manifesto of transdisciplinarity. New York: State University of New York press.

Symeonidis, V., \& Schwarz, J. F. (2016). Phenomenon-based teaching and learning through the pedagogical lenses of phenomenology: The recent curriculum reform in Finland. Forum Oświatowe, 28(2), 31-47.

Thompson Klein, J. (2004). Prospects for transdisciplinarity. Futures, 36(4), 515-526.

Ull, À., Piñero, A., Martínez Agut, M.P., \& Aznar Minguet, P. (2014). Preconcepciones y actitudes del profesorado de Magisterio ante la incorporación en su docencia de competencias para la sostenibilidad. Enseñanza de las Ciencias, 32(2), 91-112.

Vilches Peña, A., \& Gil Pérez, D. (2015). Ciencia de la Sostenibilidad: Una nueva disciplina o un nuevo enfoque para todas las disciplinas? Revista Iberoamericana de Educación, 69(1), 39-60. 